Bangladesh J. Bot. 49(3): 619-624, 2020 (September)

\title{
ALUMINIUM TOXICITY ON THE ACTIVITIES OF ANTIOXIDANT ENZYMES IN RICE (ORYZA SATIVA L.) AND CHICKPEA (CICER ARIETINUM L.) SEEDLINGS GROWN IN HYDROPONIC CULTURE
}

\author{
Rifat Samad*, Parveen Rashid and JL Karmoker \\ Department of Botany, University of Dhaka, Dhaka-1000, Bangladesh
}

Keywords: Aluminium toxicity, Antioxidant enzymes, Superoxide dismutase, Rice, Chickpea

\begin{abstract}
Effects of four different concentrations of aluminium $(10,50,100$ and $150 \mu \mathrm{M})$ on some antioxidant enzyme activities like peroxidase, catalase and superoxide dismutase of the seedlings of rice and chickpea grown in hydroponic culture showed aluminium toxicity which caused a dramatic increase in peroxidase and catalase activities in the root and shoot of rice seedlings. $\mathrm{Al}(150 \mu \mathrm{M})$ caused eight to nine-folds increase in peroxidase and catalase activity, respectively, in the root of rice seedlings. On the contrary, Al stress decreased superoxide dismutase (SOD) activity in the root and shoot of rice seedlings. In chickpea seedlings, $\mathrm{Al}$ stress caused a few-folds increases in peroxidase, catalase and SOD activities in the roots and leaves. A dramatic 14.8 and 14.6-folds increase in SOD activity was recorded in the roots and leaves of chickpea seedlings, respectively. It is noted that there is a generic difference between rice and chickpea with respect to the effect of $\mathrm{Al}$ stress on SOD activity.

\section{Introduction}

In the earth crust aluminium is the most abundant metallic element and third most abundant of all elements. At mildly acidic or neutral soil $\mathrm{pH}$ values, it occurs primarily as insoluble deposits and essentially is biologically inactive (Nasr 2013). Solubolization of Al-containing minerals is enhanced by low pH in acidic environment in many acid soils throughout the world and soluble $\mathrm{Al}^{3+}$ is the most growth-limiting factor (Foy 1988), possibly affecting 70\% of world's arable land which is potentially usable for food and biomass production (Haug and Caldwell 1985). Acid soils occupy $30-40 \%$ of the arable lands (von Uexküll and Mutert 1995) and are consequence of a rapid industrial development and environmental pollution, this area increases from year to year especially in developing countries.

The examination of antioxidant enzyme activities often serves as a key biochemical indicator to assess the sensitivity of plants under stress conditions (Sharma et al. 2012). Peroxidase, catalase and superoxide dismutase (SOD) are the key enzymes in antioxidative defense system. Reactive oxygen species (ROS) is closely related to the response of plants to heavy metals (Nagajyoti et al. 2010). Production of reactive oxygen species (ROS, $0.5 \mathrm{O}^{-}$and $\mathrm{H}_{2} \mathrm{O}_{2}$ ) is increased under various environmental stresses. These ROS cause oxidative damage to cellular organelles and biomolecules, and thus lead to several metabolic alteration (Ma 2007, Jain et al. 2008). Free radical scavenging enzymes such as peroxidase, catalase and SOD keep the cellular level of ROS under control and help to avoid oxidative damage (Ribeiro et al. 2012). Al toxicity-induced increase in peroxidase, catalase and SOD plays a vital role in aluminium stress tolerance.
\end{abstract}

*Author for correspondence: <rifatsamad@gmail.com>. 
Aluminium toxicity increased the activities of superoxide dismutase (SOD) and peroxide (POD) and glutathione reductase in greengram. On the contrary, it decreased catalase activity in the same plant (Panda et al. 2003). Al stimulated SOD activity but decreased that of catalase in pearl millet (Suresh Babu et al. 2013). In the present study, an attempt was taken to investigate the effect of aluminium toxicity on the activities of peroxidase, catalase and superoxide dismutase of rice and chickpea seedlings grown in hydroponic culture.

\section{Materials and Methods}

Rice (Oryza sativa L. var. BRRI Dhan-53), most widely consumed cereal grain of the family Poaceae and chickpea (Cicer arietinum L. var. BARI chhola-7), the third most extensively planted grain legume of the family Fabaceae were used as experimental plant materials. Seeds of rice were collected from Bangladesh Rice Research Institute (BRRI) and that of chickpea were procured from Bangladesh Agricultural Research Institute (BARI). The experiments were conducted at the Department of Botany, University of Dhaka, Dhaka, Bangladesh.

The seeds were surface sterilized according to Samad and Karmoker (2013). The sterilized seeds were spread over a cotton gauge placed in a lid having holes $(1 \mathrm{~cm}$ in diameter) and the lid with seeds was placed on a beaker containing $500 \mathrm{ml}$ of distilled water. The beakers were covered by black plastic sheet to avoid the exposure of light to the roots. After germination, the seedlings were transferred to modified half-strength Hoagland solution (Hoagland and Arnon 1950) and the beakers with the seedlings were placed in a light bank. Rice seedlings were grown at a day/night temperature of $30 \pm 1^{\circ} \mathrm{C} / 25 \pm 1^{\circ} \mathrm{C}$ and day/night length of $14 \mathrm{hrs} / 10 \mathrm{hrs}$. Chickpea seedlings were grown at a day/night temperature of $25 \pm 1^{\circ} \mathrm{C} / 18 \pm 1^{\circ} \mathrm{C}$ and day/night length of $10 \mathrm{hrs} / 14 \mathrm{hrs}$. Light intensity was $160 \mu$-einstein $/ \mathrm{m}^{2} \mathrm{~s}$. The solution was continuously aerated through bubbler with the help of air compressor (Rockyvac 320). The solution was replenished every $48 \mathrm{hrs}$. Seven-day-old seedlings were transferred to half strength Hoagland solution as control and 10, 50, 100 and $150 \mu \mathrm{M} \mathrm{AlCl}_{3}$ solution made in half strength Hoagland solution were used as treatments. The $\mathrm{pH}$ of all solutions including control were adjusted to 4.2 with $0.2 \mathrm{~N} \mathrm{H}_{2} \mathrm{SO}_{4}$.

For the determination of the activities of antioxidant enzymes, $0.5 \mathrm{~g}$ of plant sample was homogenized in $0.05 \mathrm{M}$ phosphate buffer ( $\mathrm{pH}$ 7.8). Homogenate was centrifuged at 10,000 rpm for $10 \mathrm{~min}$ at $4^{\circ} \mathrm{C}$. Supernatant was separated and used for specific enzyme assay.

The activity of peroxidase was determined by the method as described by Zhang et al. (1995). The reaction mixture consisted of $0.1 \mathrm{M}$ phosphate buffer $(\mathrm{pH} 7.8), 30 \% \mathrm{H}_{2} \mathrm{O}_{2}$ and $0.05 \mathrm{M}$ guaiacol (freshly prepared). The supernatant $(0.2) \mathrm{ml}$ was added to the reaction mixture. The change of optical density (O.D) was measured at a wavelength of $470 \mathrm{~nm}$ with a spectrophotometer for every $30 \mathrm{sec}$ for $2 \mathrm{~min}$. Peroxidase activity was expressed as $\mu \mathrm{mol} / \mathrm{min} / \mathrm{mg} /$ protein.

The catalase activity was assayed according to the method of Barber (1980). Catalase activity was measured by using assay solution containing $0.05 \mathrm{M}$ phosphate buffer ( $\mathrm{pH} 7.8$ ), $0.1 \mathrm{M} \mathrm{H}_{2} \mathrm{O}_{2}$ and $0.2 \mathrm{ml}$ extract. Decrease in absorbance of $\mathrm{H}_{2} \mathrm{O}_{2}$ was recorded within 2 min at $240 \mathrm{~nm}$. One unit of catalase activity was defined as the amount of enzyme required to reduce $1 \mu \mathrm{mol}$ of $\mathrm{H}_{2} \mathrm{O}_{2}$ per min. Catalase activity was expressed as $\mu \mathrm{mol} / \mathrm{min} / \mathrm{mg} /$ protein.

The superoxide dismutase (SOD) activity was determined according to the modified method of Zhang et al. (2005). The SOD activity was determined by measuring the inhibition of the photochemical reduction of nitroblue tetrazolium chloride (NBT). The reagents used for assay included $50 \mathrm{mM}$ phosphate buffer (pH 7.8), $130 \mathrm{mmol} / 1$ methionine, $750 \mu \mathrm{mol} / 1 \mathrm{NBT}, 100 \mu \mathrm{mol} / \mathrm{l}$ $\mathrm{Na}_{2}$-EDTA and $20 \mu \mathrm{mol} / \mathrm{l}$ riboflavin. After adding $1 \mathrm{ml}$ of supernatant (extract) to the reaction mixture, the test tubes were exposed for 10 mins to fluorescent light $(13 \mathrm{~W})$. Then the change in 
absorbance was followed up to $2 \mathrm{~min}$ at a wavelength of $560 \mathrm{~nm}$ using a spectrophotometer (Shimadzu, Model: UV-1800, Japan). One unit of SOD was defined as the amount of enzyme required to inhibit NBT reduction by $50 \%$ under specified conditions of the assay. SOD activity was expressed as unit $\mathrm{min} / \mathrm{mg} /$ protein.

\section{Results and Discussion}

Peroxidase activity was found to increase in the root of rice by $4-7.9$-folds following $96 \mathrm{hrs}$ of exposure to 10 to $150 \mu \mathrm{M} \mathrm{Al}$ (Fig. 1a). In the shoot of rice, a 1.8 - 2.9-folds stimulation of peroxidase activity was recorded at 10 to $150 \mu \mathrm{M} \mathrm{Al}$ application, respectively (Fig. 1b).

Similarly, Al $(10 \mu \mathrm{M})$ increased peroxidase activity in the root of chickpea seedlings by $29.5 \%$ at $96 \mathrm{hrs}$ of treatment. The 50 to $150 \mu \mathrm{M} \mathrm{Al}$ caused a $3.7-4.8$ times stimulation of peroxidase activity in the root (Fig. 2a). In the leaves of chickpea, 10 to $150 \mu \mathrm{M} \mathrm{Al}$ increased peroxidase activity by 2 - 13-folds at 96 hrs of application (Fig. 2b).
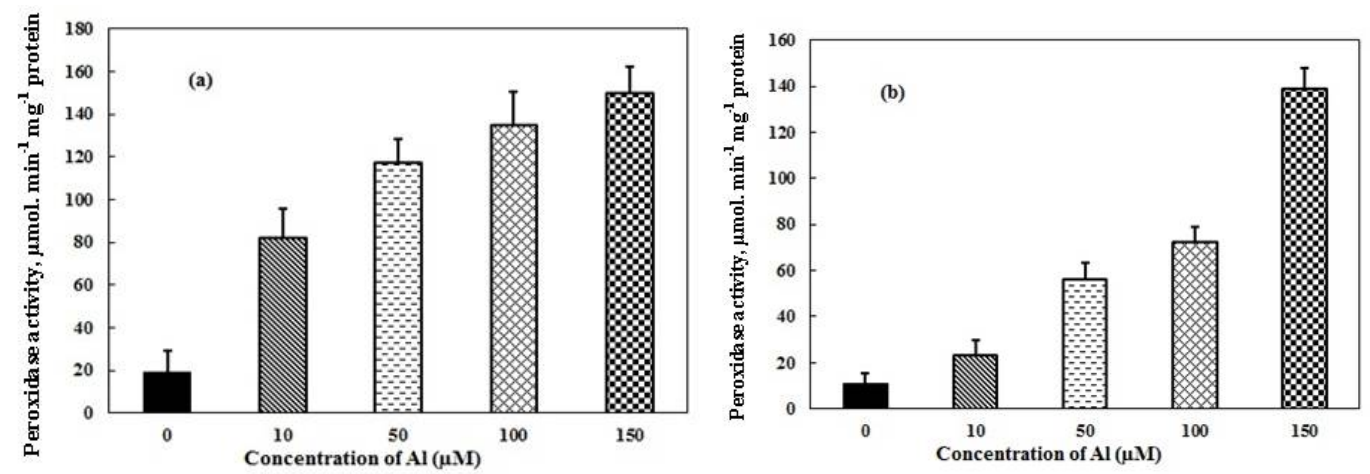

Fig. 1. Effects of different concentrations of aluminium on the activity of peroxidase in : (a) root and (b) shoot of rice seedlings grown in solution culture at $96 \mathrm{hrs}$ of treatment. $\mathbf{a}$ represents control; $\mathbb{N} 10$ $\mu \mathrm{M} A l,=50 \mu \mathrm{M} \mathrm{Al}, \widehat{=} 100 \mu \mathrm{M} \mathrm{Al}$ and $150 \mu \mathrm{M}$ Al. Each value is the mean of three replicates \pm standard error.
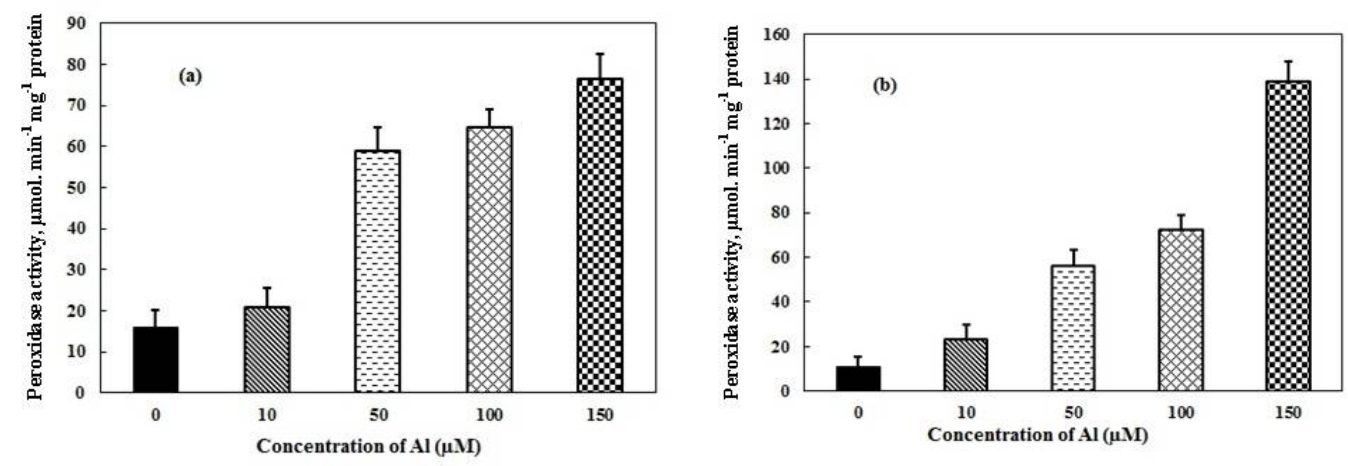

Fig. 2. Effects of different concentrations of aluminium on the activity of peroxidase in : (a) root and (b) leaves of chickpea seedlings grown in solution culture at $96 \mathrm{hrs}$ of treatment. Otherwise as Fig. 1. 
Catalase activity in the root of rice was stimulated by Al stress. The 50, 100 and $150 \mu \mathrm{M} \mathrm{Al}$ caused a 2.8, 5 and 9-folds increase in catalase activity in the root, respectively, at 96 hrs of exposure (Fig. 3a). In the shoot of rice, 10 to $150 \mu \mathrm{M} \mathrm{Al}$ increased the activity of catalase by $38.4 \%$ to 3.5 -folds at $96 \mathrm{hrs}$ of treatment (Fig. 3b).
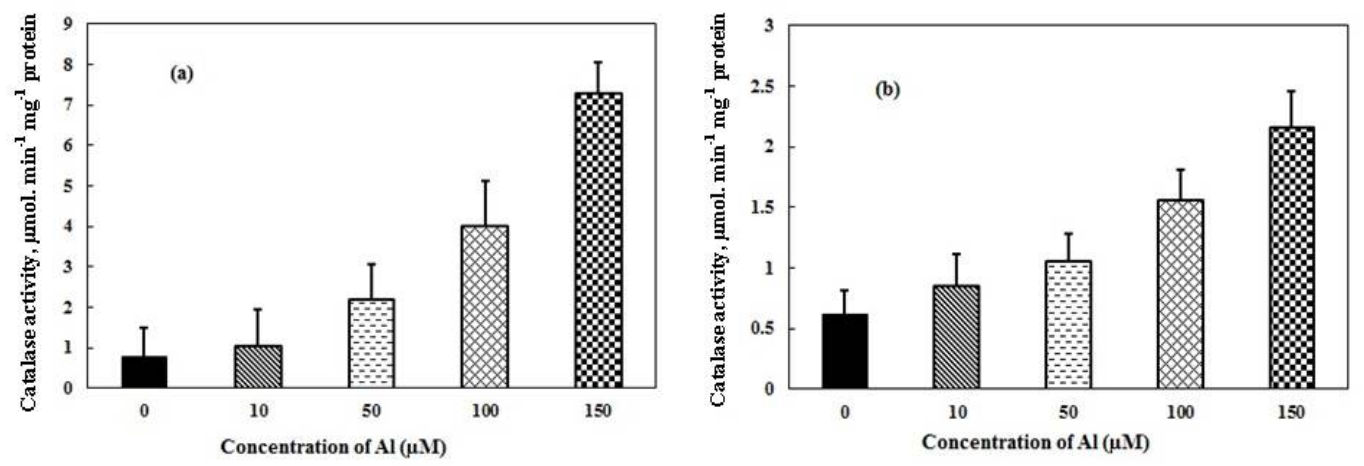

Fig. 3. Effects of different concentrations of aluminium on the activity of catalase in : (a) root and (b) shoot of rice seedlings grown in solution culture at $96 \mathrm{hrs}$ of treatment. Otherwise as Fig. 1.
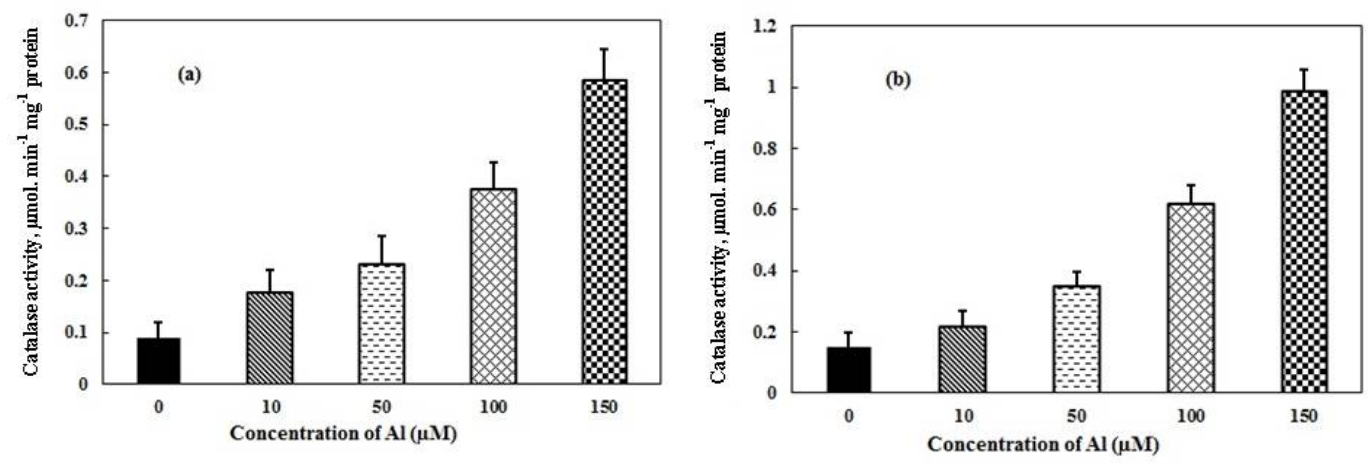

Fig. 4. Effects of different concentrations of aluminium on the activity of catalase in : (a) root and (b) leaves of chickpea seedlings grown in solution culture at $96 \mathrm{hrs}$ of treatment. Otherwise as Fig. 1.

Similar stimulatory effect on catalase activity was also observed in the root and leaves of chickpea. Al (10 to $150 \mu \mathrm{M})$ progressively increased the activity of catalase from $98.9 \%$ to 6.6 folds in the root of chickpea at $96 \mathrm{hrs}$ of exposure (Fig. 4a). In the leaves of chickpea, all the concentrations of $\mathrm{Al}(10$ to $150 \mu \mathrm{M})$ increased catalase activity. The increase of catalase activity in the leaves was $2.3-6.5$ times following exposure to $50-150 \mu \mathrm{M} \mathrm{Al}$ (Fig. 4b).

$\mathrm{Al}$ stress decreased SOD activity in the root of rice. Aluminium $(10-150 \mu \mathrm{M})$ inhibited SOD activity by $14.8-50.0 \%$ in the root of rice at $96 \mathrm{hrs}$ of exposure (Fig. 5a). In the shoot of rice, $\mathrm{Al}$ $(10-150 \mu \mathrm{M})$ decreased SOD activity by $15.7-47.0 \%$ at $96 \mathrm{hrs}$ of treatment (Fig. 5b).

On the contrary, $\mathrm{Al}(10 \mu \mathrm{M})$ increased SOD activity in the root of chickpea by $48.7 \%$ at 96 hrs of exposure. SOD activity increased with the increase in Al concentration from $50-150 \mu \mathrm{M}$. A dramatic 14.8 times increase in SOD activity was recorded in the root following $150 \mu \mathrm{M} \mathrm{Al}$ treatment (Fig. 6a). Similarly, SOD activity was found to increase in the leaves following 10 to $150 \mu \mathrm{M} \mathrm{Al}$ application. One hundred and $150 \mu \mathrm{M}$ Al caused a dramatic 9.5 - 14.6-folds stimulation of SOD activity, respectively in the leaves, at $96 \mathrm{hrs}$ of exposure (Fig. 6b). 
Aluminium stress caused a maximum increase in the activity of peroxidase and catalase but decreased that of SOD in the root and the shoot of rice seedlings (Figs 1, 3 and 5). However, $\mathrm{Al}$ treatment caused a few-folds stimulation of the activities of peroxidase, catalase and SOD in the root and leaves of chickpea seedlings (Figs. 2, 4 and 6). Similar aluminium toxicity-induced stimulation of the activities of peroxidase, and SOD was found in tomato (Surapu et al. 2014). On the contrary, Al caused an inhibition of catalase activity in tomato (Surapu et al. 2014). Giannakoula et al. (2010) and Ma et al. (2012) working with two maize and rice cultivars with different tolerance to $\mathrm{Al}$, respectively showed that the improvement in protection against $\mathrm{Al}$ toxicity was obtained by an increase in the activity of the antioxidant enzymes. Lee et al. (2001) suggested that SOD might function in signaling of oxidative stress which might lead to the induction of antioxidant enzymes associated with a $1 / 2 \mathrm{O}_{2}$ scavenging system.
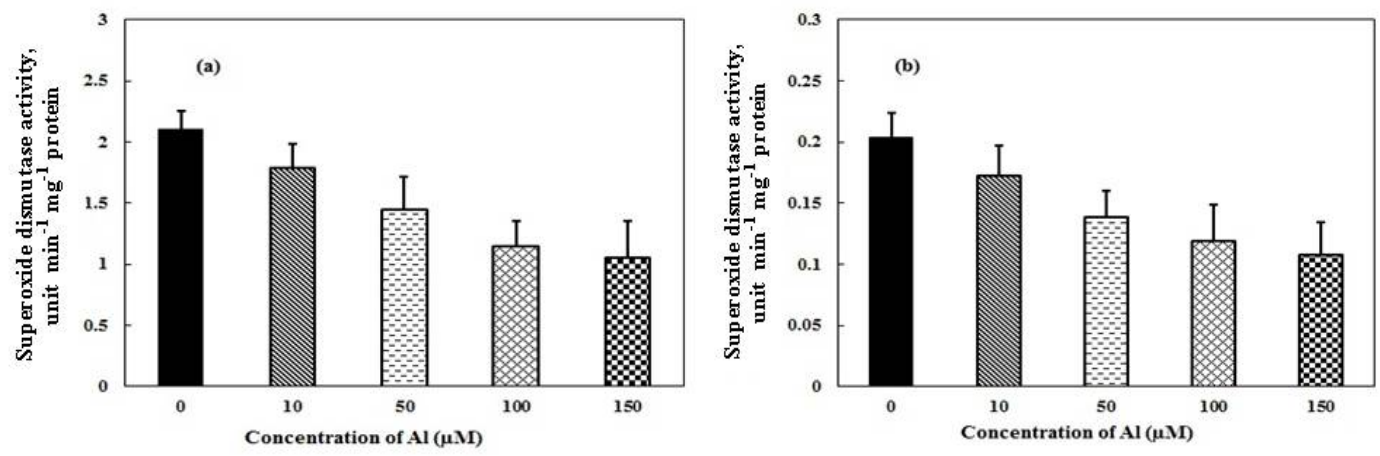

Fig. 5. Effects of different concentrations of aluminium on the activity of superoxide dismutase in: (a) root and (b) shoot of rice seedlings grown in solution culture at $96 \mathrm{hrs}$ of treatment. Otherwise as Fig. 1.
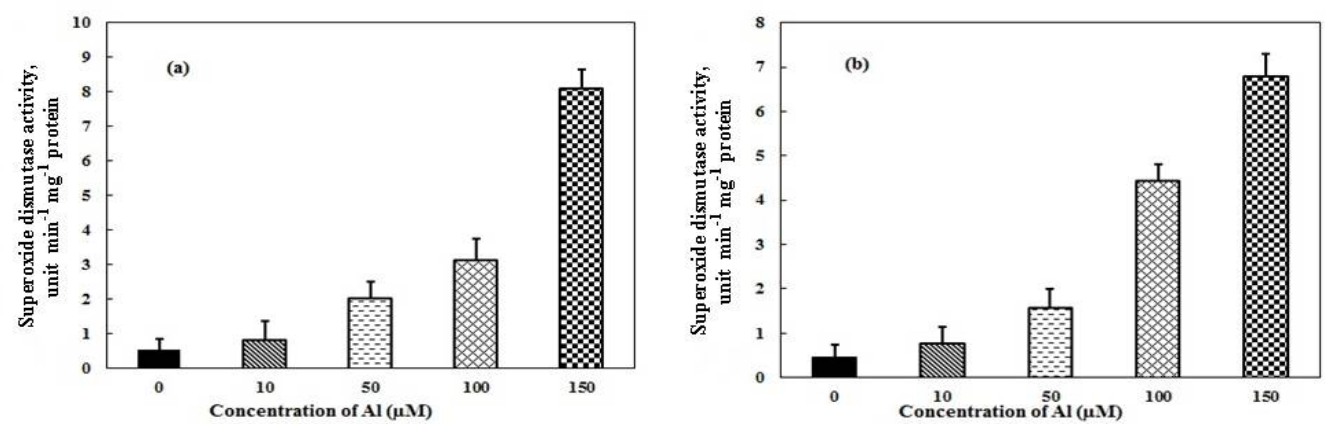

Fig. 6. Effects of different concentrations of aluminium on the activity of superoxide dismutase in : (a) root and (b) leaves of chickpea seedlings grown in solution culture at $96 \mathrm{hrs}$ of treatment. Otherwise as Fig. 1.

Antioxidant enzyme activities serve as a key biochemical indicator to assess the sensitivity of plants under stress condition. Al triggers an increased production of ROS which includes singlet oxygen $\left(0.5 \mathrm{O}_{2}^{-}\right)$, superoxide radical $\left(\mathrm{O}_{2}\right)$, hydroxyl radical $(\mathrm{OH})$ and $\mathrm{H}_{2} \mathrm{O}_{2}$ in the tissue. ROS causes damage to lipid, protein and nucleic acid in the cells. The most effective antioxidant enzymes preventing ROS-induced cellular oxidative damage is SOD which catalyzes the conversion of $0.5 \mathrm{O}_{2}^{-}$to $\mathrm{H}_{2} \mathrm{O}_{2}$ whereas catalase scavenges $\mathrm{H}_{2} \mathrm{O}_{2}$ and peroxidase use $\mathrm{H}_{2} \mathrm{O}_{2}$ for oxidation of various organic substrates. Thus, Al-induced increase in activities of antioxidant enzymes peroxidase, catalase and SOD play a vital role in tolerance of plant under Al-stress. 


\section{References}

Barber JM 1980. Catalase and peroxidase in primary leaves during development and senescence. Z. Pflanzenphysiol. 97: 135-44.

Foy CD 1988. Plant adaptation to acid, aluminium-toxic soils. Commun. Soil Sci. Plant Analy. 19: 959-987.

Giannakoula A, Moustakas M, Syros T and Yupsanis T 2010. Aluminium stress induces up-regulation of an efficient antioxidant system in the Al-tolerant maize line but not in the Al-sensitive line. Environ. Expt. Bot. 67: 487-494.

Haug AR and Caldwell CR 1985. Aluminium toxicity in plants: the role of the root plasma membrane and calmodulin. In: John St JB, Berline, Jackson PC, (eds.) Frontiers of Membrane Research in Agriculture, Beltsville Symp. 9. Totowa, USA : Rowman and Allanheld, pp. 359-381.

Hoagland DR and Arnon DI 1950. The water culture method for growing plants without soils. Berkeley: California Agricultural Experimental Station, pp. 347.

Jain LY, Ya YL, Yue JZ, Shan Z, Yun RW, Ping W and Shao JZ 2008. Cell wall polysaccharides are specifically involved in the exclusion of aluminium from the rice root apex. Plant Physiol. 146: 602611.

Lee DH, Kim YS and Lee CB 2001. The inductive responses of the antioxidant enzymes by salt stress in the rice (Oryza sativa_L.). Plant Physiol. 158: 737-745.

Ma JF 2007. Syndrome of aluminium toxicity and diversity of aluminium resistance in higher plants. Int. Rev. Cytol. 264: 225-252.

Ma B, Gao L, Zhang H, Cui J and Shen Z 2012. Aluminium-induced oxidative stress and changes in antioxidant defenses in the roots of rice varieties differing in Al tolerance. Plant Cell Rep. 31: 687-696.

Nagajyoti PC, Lee KD and Sreekanth TVM 2010. Heavy metals occurrence and toxicity for plants. Environ. Chem. Letters 8: 199-216.

Nasr N 2013. Germination and seedling growth of maize (Zea mays L.) seeds in toxicity of aluminium and nickel. Merit Res. J. Environ. Sci. Toxicol. 1: 110-113.

Panda SK, Singha LB and Khan MH 2003. Does aluminium phytotoxicity induce oxidative stress in greengram (Vigna radiata)? Bulg. J. Plant Physiol. 29: 77-86.

Ribeiro C, Cambraia J, Peixoto PHP and Fonseca Junior EM 2012. Antioxidant system response induced by aluminum in two rice cultivars. Braz. J. Plant Physiol. 24: 107-116.

Samad R and Karmoker JL 2013. Effects of $\mathrm{NaCl}$ salinity stress on accumulation of $\mathrm{K}^{+}, \mathrm{Na}^{+}, \mathrm{Cl}^{-}, \mathrm{NO}_{3}{ }^{-}$, sugar and proline contents in the seedlings of Triticale-I. Bangladesh J. Bot. 42: 189-194.

Sharma P, Bhushanm A, Dubey RS and Pessarakli M 2012. Reactive oxygen species, oxidative damage and antioxidant defense mechanism in plants under stressful conditions. J. Bot. 26: 1-26.

Surapu V, Ediga A and Meriga B 2014. Salicylic acid alleviates aluminum toxicity in tomato seedlings (Lycopersicum esculentum Mill.) through activation of antioxidant defense system and proline biosynthesis. Adv. Biosci. Biotech. 5: 777-789.

Suresh Babu B, Muniswamy D, Radhaiah A and Reddy PLN 2013. Aluminium induced phytotoxic effect on antioxidant enzyme activities in pearl millet varieties Nandi 32 and Nirmal 9. Indian J. Fund. Appl. Life Sci. 3: 252-258.

von Uexküll HR and Mutert E 1995. Global extent, development and economic impact of acid soils. Plant Soil 171: 1-15.

Zhang H, Jiang Y, He Z and Ma M 2005. Cadmium accumulation and oxidative burst in garlic (Allium sativum). J. Plant Physiol. 162: 977-984.

Zhang J, Cui S, Li J and Kirkham MB 1995. Protoplasmic factors, antioxidant responses, and chilling resistance in maize. Plant Physiol. Biochem. 33: 567-75.

(Manuscript received on 3 April, 2019; revised on 10 December, 2019) 